\title{
Mesajul Președintelui SRUMB
}

Ultrasonografia este o componentă a diagnosticului imagistic și face parte din practica medicală de zi cu zi. În medicina modernă, tot mai tehnologizată, ultrasonografia ocupă un loc de prim plan între metodele de diagnostic imagistic, fiind adesea nu doar metoda de primă intenție ci chiar metoda finală de diagnostic. Raționamentul clinic nu poate fi înlocuit de nici o metodă de diagnostic, dar trebuie susținut de toate metodele.

Grație tehnologiilor deja intrate în arsenalul ultrasonografic (transductoare cu frecvențe mari, armonici superioare, metode Doppler, substanță de contrast, elastografie, etc ) în paralel cu creșterea competenței examinatorului, metoda a atins azi performanțe nebănuite în urmă cu câțiva ani.

Progresul tehnologic a permis introducerea ultrasonografiei în arsenalul terapeutic, printr-o serie de proceduri minim invazive, ghidate ecografic.

Dependenți de tehnologie și de noutatea informației, noi cei care practicăm ultrasonografia - pe nivele de competență diferite - am simțit de mult nevoia să ne organizăm într-o societate profesională în care să schimbăm idei, să aflăm păreri competente, să comunicăm rezultate. Gândită la început ca un fel de club (am fost inițial câteva zeci de membri fondatori), Societatea Română de Ultrasonografie în Medicină și Biologie a crescut numeric și ca valoare profesională de-a lungul anilor, s-a structurat, s-a diversificat, a dat naștere altor societăți paralele și a intrat în marea familie a societăților europene și mondiale.

Societatea noastră se întărește prin a-fluxul de noi membrii. Simultan, membrii societății beneficiază de o serie de facilități care asigură accesul la informația medicală ultrasonografică de cea mai înaltă calitate prin intermediul unor cursuri, conferințe, congrese și reviste de specialitate.

Recent revista de ultrasonografie (Medical Ultrasonography) editată de societate

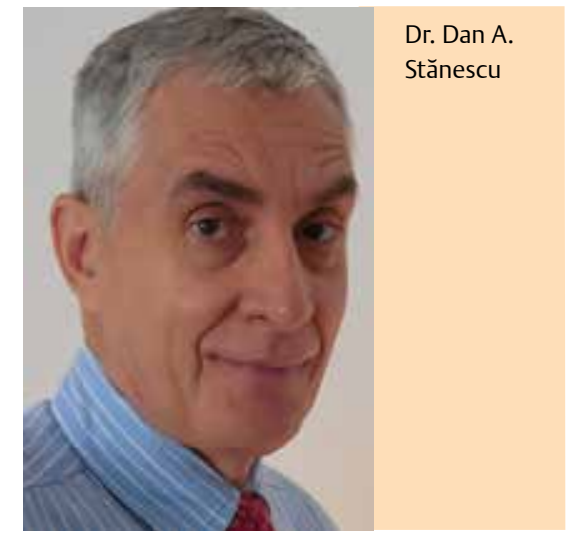

a căpătat noi valențe prin creșterea cotației internaționale (Science Citation Index Expanded ${ }^{\mathrm{TM}} /$ ISI Thomson Master Journal List ). Acest fapt a venit ca 0 recunoaștere internațională a calității articolelor publicate, majoritatea de către membrii societății, precum și a eficienței activității de coordonare depusă de colectivul editorial. Forța societății noastre constă în calitatea și numărul membrilor noștri. Ne dorim o societate puternică și pentru ca părerea noastră să conteze în luarea celor mai bune decizii privind viitorul ultrasonografiei în România.

Urez Societății Române de Ultrasonografie viață lungă și să se întărească permanent profesional.

Invit toți membrii societății ca și pe toți practicanții metodei ultrasonografice să ne reunim în marea familie a ecografiștilor din România cu ocazia Conferinței a XVIIIa de la Constanța din 25 -27 iunie 2015.

\section{Dr. Dan A. Stănescu}

Președinte executiv

Societatea Română de Ultrasonografie în Medicină și Biologie (SRUMB) 